Prethodno priopćenje UDK 274(045)

doi: $10.21464 /$ fi38403

Primljeno: 30. 4. 2018.

\title{
Darko Pirija
}

Adventističko teološko visoko učilište, Maruševec 82, HR-42243 Maruševec pirijad@gmail.com

\section{Sloboda, pravda i mir \\ Budućnost reformacijske baštine u dijalogu sa suvremenom apokaliptičkom teologijom}

\begin{abstract}
Sažetak
Daljnja afirmacija reformacijske teološke baštine u suvremenim europskim kulturama zahtijeva njezinu stvaralačku reinterpretaciju, tako da bi se očuvala izvorna vrijednost njezinih temeljnih teoloških sadržaja, a istovremeno odgovorilo na nova pitanja $i$ dvojbe koje proizlaze iz slojevitog kulturnog habitusa kasne moderne. Sadržajno preusmjeravanje reformacijske teologije treba, umjesto logosa moderne, slijediti logos Božje stvarnosti u teorijskim, metodološkim i epistemološkim okvirima koji će jamčiti ravnopravan i plodonosan dijalog teologije i kulture. Ideale mira, slobode i pravde moguće je ostvarivati na temelju vjere u božansko-ljudsko supostojanje, ukorijenjene u suvremenoj apokaliptičkoj teologiji koja se oslanja na tradicionalni reformacijski nauk o grijehu i pokajanju, ali s novim naglaskom na sadašnji i budući vid Kristove apokalipse. Življenjem novog života u Kristu, na osobnoj i socijalnoj razini u društvenu se svijest upisuju novi obrasci življenja koji svjedoče o punini života utemeljenog na vjeri u preobražavajuće djelovanje Božje prisutnosti u vremenitom poretku i nadi u konačno razrješenje zla u Božjoj obećanoj budućnosti.
\end{abstract}

\section{Ključne riječi}

sloboda, mir, pravda, Miroslav Volf, Charles Taylor, Jacques Ellul, Jürgen Moltmann, reformacija, apokaliptička eshatologija, pokajanje

\section{Uvod}

Povodom obilježavanja pet stoljeća reformacije, suštinski je važno propitivati narav i funkciju osobnog i kolektivnog pamćenja kršćanske teološke tradicije te uvijek iznova tražiti konkretne odgovore na pitanje: što znači pamtiti ispravno? ${ }^{1}$ Teološko poimanje pamćenja koje se zagovara u ovom radu oblikovano je u djelokrugu vjere u biblijsko tumačenje supostojanja Boga i čovjeka, u kategorijama suvremene apokaliptičke teologije ${ }^{2}$ te u okvirima

1

Za opsežniju raspravu o naravi i funkciji teološkog pamćenja na koje se oslanja ovaj rad vidi: Miroslav Volf, Zrcalo sjećanja, preveo Roman Karlović, Ex libris, Rijeka 2011.; Avishai Margalit, The Ethics of Memory, Harvard University Press, Cambridge 2002. Potrebno je napomenuti kako se Wieselova tvrdnja da »pravda bez pamćenja nepotpuna je pravda, lažna i nepravedna« može jednako primijeniti i na pitanje pomirenja i slobode.
Vidi: Elie Wiesel, From the Kingdom of Memory: Reminiscences, Summit Books, New York 1990., str. 187.

2

Za potpuniji uvid u sadržaj suvremene apokaliptičke teologije vidi: Philip G. Ziegler, Militant Grace: The Apocalyptic Turn and the Future of Christian Theology, Baker Academic, Grand Rapids 2018.; Christiaan Beker, 
kritičkog realizma kao prvenstveno metateorijskog stajališta nužnog za promišljanje složenog odnosa teologije i kulture. ${ }^{3} \mathrm{U}$ središtu ovog teološki određenog pamćenja reformacijske baštine raspeti je i uskrsli Isus Krist, eshatološki telos ljudske povijesti koji je svojim činom pomirenja presudno povezao ljudsku sadašnjost i budućnost i odredio njihov sadržaj. Pamćenje utjelovljenoga Krista odgovor je na mogućnost Halbwaschsova »mrtvog pamćenja« i Ricœurova posve oprečnog pamćenja čija je obveza činiti pravdu drugome. ${ }^{4}$ Istovremeno, bitna je i etičko-retorička dimenzija teološke interpretacije koja, prema Schüssler Fiorenzi, treba biti društveno angažirana znanost usmjerena življenju slobode, pravde i pomirenja kao temeljnih odrednica ljudske egzistencije. ${ }^{5}$

Metodološki, ovaj se rad oslanja na Wolterstorffovo načelo »dijaloškog pluralizma $\aleph^{6}$ ne samo zato što ga smatram izrazito prikladnim za međureligijski dijalog, kao i za dijalog između teološke i sekularne misli, nego i zato što je sukladan poimanju vrednota slobode, pravde i pomirenja koje smatram presudnim za suvremeno, stvaralačko tumačenje reformacijske baštine. ${ }^{7} \mathrm{U}$ okvirima ovog temeljnog metodološkog pristupa treba razumjeti i iznimno važan Pannenbergov uvid o funkciji kršćanske eshatologije kao kritičke i konstruktivne znanosti čija onostrana narav »naviješta eshatološko kraljevstvo Božje kao prostor za ostvarenje istinskog mira i pravde među ljudskim bićima «. ${ }^{8}$

Nadalje, i suvremena apokaliptička eshatologija, shvaćena prvenstveno kao apokaliptičko evanđelje Isusa Krista, čini referentni okvir ovog rada, čime se poštuje i apokaliptičku narav Lutherove reformacijske misli, ${ }^{9}$ ali se nastoji i stvaralački tumačiti uloga teoloških sadržaja reformacijske baštine u suvremenom europskom kulturnom habitusu. ${ }^{10}$ Prikladan je primjer ovakvog stvaralačkog tumačenja $\mathrm{M}$. de Boerovo poimanje apokaliptičke eshatologije kao božanskog otkrivenja koje u sebi sadrži i osobni i kozmički, kao i sadašnji i budući vid božansko-ljudskog odnosa te se »u osnovi bavi s Božjim aktivnim i vidljivim iscjeljenjem stvorenog svijeta koji je nekako zastranio i postao otuđen od Boga«. ${ }^{11}$ Tumačeći narav eshatološke različitosti kršćanske zajednice u odnosu Crkve i kulture, Volf pobliže objašnjava ovu otuđenost riječima »On je [Isus Krist, op. aut.] (...) bio stranac svijetu jer je svijet u koji je došao bio otuđen od Boga." (Iv 1,11), pretpostavljajući da ova temeljna vrsta otuđenosti određuje sve druge oblike osobnih i društvenih otuđenja. ${ }^{12}$ Prije daljnjeg razmatranja značaja reformacijske baštine za europska društvena strujanja potrebno je skicirati značajnija očitovanja ove otuđenosti u djelokrugu kulturnog habitusa kasne moderne.

\section{Slojevit kulturni habitus kasne moderne}

Pitanje suodnosa Boga, čovjeka i prirodnog svijeta nije bilo samo nedoumica kasnog srednjovjekovlja i reformacije, nego je to ključna tema koju treba nastaviti razmatrati ako se reformacijsku misao želi i dalje afirmirati u suvremenim europskim kulturnim strujanjima. Ako se, slijedeći Gillespiea, ${ }^{13}$ kasnomodernu misao, kao i kasnosrednjovjekovnu teologiju i filozofiju, može razumjeti kao trajnu potragu za novim metafizičkim i teološkim tumačenjima odnosa Boga, čovjeka i prirodnog svijeta, uzrokovanu unutarnjim napetostima u kršćanskoj teologiji ${ }_{14}^{14}$ potrebno je razmotriti temeljno obilježje ovog suodnosa, otuđenost svijeta od Boga (Iv 1,11), a čovjekovo odbacivanje Boga kao njezin prvenstveni uzrok (Ellul). ${ }^{15}$ Suvremeni suživot teologije i moderne misli može se, dakle, promatrati kao daljnji niz pokušaja ustanovljavanja nove i dosljednije metafizike i kršćanske teologije. ${ }^{16}$ 
Međutim, David Tracy primjećuje da u ovim pokušajima sadržaje kršćanskih teologija, proizašlih iz moderne, često »ne određuje Božja stvarnost, nego logos moderne «, ${ }^{17}$ čak i nakon kulturnog »okretanju Bogu « u kasnoj moderni. Tracy ovdje ukazuje na izrazito asimetričan odnos kršćanske teologije i mo-

Paul's Apocalyptic Gospel: The Coming Triumph of God, Fortress Press, Minneapolis 2007.; Joshua B. Davies, Douglas Harink, Apocalyptic and the Future of Theology: With and Beyond J. Louis Martyn, Wipf and Stock Publishers, Eugene 2012.; Martinus C. de Boer, »Paul and Apocalyptic Eschatology«, u: John J. Collins (ur.), The Encyclopedia of Apocalypticism: The Origins of Apocalypticism in Judaism and Christianity, The Continuum Publishing Company, New York 2006.; Philip G. Ziegler, »Dietrich Bonhoeffer - an Ethics of God's Apocalypse? «, Modern Theology 23 (2007) 4, str. 579-594, doi: https:// doi.org/10.1111/j.1468-0025.2007.00410.x Beverly Roberts Gaventa (ur.), Apocalyptic Paul: Cosmos and Anthropos in Romans 5-8, Baylor University Press, Waco 2013

3

Za sažeto razmatranje kritičkog realizma kao metateorijskog okvira za razumijevanje odnosa teologije i znanosti koji zagovaram u ovom članku vidi: Ante Jerončić, »The Quest for 'La Sapienza': Roy Bhaskar's Critical Realism and the Science and Religion Dialogue«, Andrews University Seminary Studies 53 (2015) 2, str. 355-368.

Paul Ricœur, Memory, History, Forgetting, preveli Kathleen Blamey, David Pellauer, University of Chicago Press, Chicago 2004., str. 89. doi: https://doi.org/10.7208/chicago/9780226713465.001.0001.

5

Unatoč značajnim metodološkim i sadržajnim razlikama u razumijevanju etičko-retoričkog vida teološkog promišljanja, prijed$\log$ Schüssler Fiorenzin smatram vrijednim doprinosom razmatranju ovog pitanja. Vidi: Elizabeth Schüssler Fiorenza, Rhetoric and Ethic: The Politics of Biblical Studies, Minneapolis, Fortress Press 1999. Pri tome, treba imati na umu i Websterovu tvrdnju da »svako etičko promišljanje u sebi sadrži prešutnu ili izrečenu antropologiju i ontologiju povijest - stvaranje moralnog subjekta i prostora unutar kojeg ovaj moralni subjekt djeluje«. Vidi: John Webster, Barth's Ethics of Reconciliation, Cambridge University Press, Cambridge 1995., str. 98 .

Wolterstorffov dijaloški pluralizam, posve oprečan filozofskom fundacionalizmu analitičke filozofije, obilježava ideja da je: »Akademsko djelovanje (...) dijalog između osoba različitih motrišta. Cilj ovog nastojanja ostaje postizanje suglasja (...). Premda suglasje nije uvjet ovog nastojanja, ono ostaje cilj. Usput, mi ne samo da prihvaćamo ili odbacujemo ono što naše kolege filozofi ili preteče kažu; mi za svoje potrebe usvajamo misli iz onoga što oni kažu (...). Ovaj suptilni postupak usvajanja temeljan je za filozofsko mišljenje. On je fundamentalan i za dijalog između teističkih i sekularnih mislioca.« Vidi: Nicholas Wolterstorff, Justice: Rights and Wrongs, Princeton University Press, Princeton 2008. str. xi-xii, doi: https://doi.org/10.1515/97814 00828715 .

7

Sintagma »reformacijska baština« obuhvaća i luteranski i reformirani pravac te pokret radikalne reformacije kao i zajednice vjernika, pokrete i teologije koji su kasnije proizašli iz njih. Autor u ovom radu ne citira, osim sporadično, izvorne reformacijske tekstove, nego se prvenstveno oslanja na suvremene protestantske teologe dvadesetog i dvadeset prvog stoljeća čije teološke doprinose smatra vjerodostojnim izričajima izvorne reformacijske misli.

Wolfhart Pannenberg, »Constructive and Critical Functions of Christian Eschatology«, Harvard Theological Review 77 (1984) 2, str. 119-139, str. 123-125, doi: https://doi. org/10.1017/s0017816000014255. U ovom članku Pannenberg se posebno obraća onima koji dovode u pitanje onostranu narav kršćanske eshatologije, ističući kako je očuvanje i razvijanje upravo toga temeljnog obilježja presudno za konstruktivnu i kritičku ulogu koju ona treba odigrati u suvremenim europskim društvima. Usp. ibid., str. 123-124.

9

Za uvodno razmatranje Lutherove apokaliptičke misli vidi: Michael Parsons, »The Apocalyptic Luther: His Noahic Self-Understanding «, JETS 44 (2001) 4, str. 627-645.

10

Zbog kratkoće rada autor je iz rasprave izostavio istovremeni kritički osvrt na apokaliptičku teologiju. Za novija kritička vrednovanja ovog teološkog pravca vidi: Jörg Frey, »Demythologizing Apocalyptic? On N. T. Wright's Paul, Apocalyptic Interpretation, and the Constraints of Construction «, $\mathrm{u}$ : Christoph Heilig, J. Thomas Hewitt, Michael F. Bird (ur.), God and the Faithfulness of Paul: A Critical Examination of the Pauline Theology of N. T. Wright, Mohr Siebeck, Tübingen 2016., str. 502-527; J. P. Davies, Paul Among the Apocaylpses? An Evaluation of the 'Apocalyptic Paul' in the Context of 
derne misli na koji apokaliptička teologija pokušava odgovoriti tako što u središte svog dijaloga sa suvremenim misaonim strujanjima stavlja načela Solus Christus i Sola Scriptura. ${ }^{18}$ Slično misli i Hans Frei ${ }^{19}$ kada tvrdi da su znanstveni ugled i kulturna vjerodostojnost suvremene teologije stečeni nekritičkim usvajanjem interpretacijskih pristupa moderne i posljedičnim odricanjem od partikularnosti biblijske naracije i singularnosti mythosa Isusa Krista. ${ }^{20}$

I Taylorovo tumačenje odnosa kršćanske i sekularne misli koje se bitno razlikuje od dvije do tada prevladavajuće teorije sekularizacije ${ }^{21}$ zaslužuju kratak osvrt jer upućuju na jedan možebitni uzrok ovog asimetričnog odnosa. On posebno ističe promijenjene »uvjete vjerovanja« i prevladavajući »isključivi humanizam « kao referentni misaoni okvir unutar kojeg se nekritičko vjerovanje u Boga danas čini gotovo nemogućim. ${ }^{22}$ Imanentni okvir unutar kojeg se promišlja ljudska egzistencija više ne ostavlja prostor za transcendentnu dimenziju moralnog poretka i transcendentni telos ljudske egzistencije. Ovako vodoravno postavljen moderni moralni poredak s naglaskom na progres, shvaćen isključivo u granicama imanentno određenih ciljeva ljudske egzistencije, onemogućuje poimanje života u kršćanskim kategorijama milosti, utjelovljenja, uskrsnuća, ili okomito posredovanim strukturama koje bi otvorile put za bitno drugačije poimanje ljudske egzistencije.

Za Taylora, ključna razlika između suvremene kulture i kulture kasnog srednjeg vijeka počiva na različitim poimanjima »punine života«. On primjećuje da smo od »stanja u kojem nas naše najviše duhovne i moralne težnje neizbježno usmjeravaju na Boga, ili može se reći, nemaju smisla bez Boga«, dospjeli u »stanje u kojem se one mogu povezati s mnoštvom različitih izvora, a često su i pripisani izvorima koji niječu Boga« ${ }^{23}$ Ukratko, moderan čovjek živi u okvirima isključivog, imanentnog humanizma koji mu ne omogućuje iskorak izvan misaonih okvira svijeta koji je sam postulirao i ispunio vlastitim sadržajima. Čovjek više ne može tragati za istinom o sebi i svijetu, za temeljima morala i punine života izvan strogo zadanih okvira vlastite socijalne imaginacije. ${ }^{24}$

Zbog ovakvog razvoja, Taylor, suprotno uvriježenom sociološkom tumačenju religioznosti koja se povlači i gotovo nestaje pred naletom sekularizacije, posebno ističe pojavu novih oblika religioznosti prilagođenih kulturi moderne. ${ }^{25}$ Ipak, ovi novi oblici postprosvjetiteljske religioznosti sve su više znak duboke krize društava kasne moderne, a sve su manje znak obećanog progresa i željene emancipacije čovjeka moderne.

Međutim, promjene nisu samo vidljive u sekularnom miljeu. I glavne kršćanske zajednice, tvrdi Taylor, poistovjetile su se s građanskim moralnim zakonom i umjesto poruke spasenja postale bedem »civilizacije« i zaštitnicima postojećeg društvenog poretka. Postepeno se odustalo od ideje o Bogu čije su nakane za ljudski život izvan ovozemaljskog napretka, a na pitanje »Što su Božje nakane za nas? ${ }^{26}$ nudi se jednostavan odgovor: »zaštititi život, donijeti blagostanje i riješiti patnju«. Volf ovakav gubitak izvornog kršćanskog identiteta naziva $»$ sakralizacijom kulturnog identiteta ${ }^{27}$

Zato, primjerice, Bonhoeffer može govoriti i o »zapadnjačkom bezboštvu« i »pobožanstvenju čovjeka ${ }^{28}{ }^{2}$ u okrilju kršćanstva koje se u obliku nacionalizma, socijalizma, racionalizma ili mistike okreće protiv živog Boga Biblije, protiv Krista. »Tu se u liku Božjem, čak Isusa Krista, obožava čovjek«, smatra on i onda ide i korak dalje tvrdeći kako "postoji obećavajuće bezboštvo koje zbori antireligiozno i anti-Crkveno. Ono predstavlja protest protiv pobožnog bezboštva, (...) štiteći na taj način, makar u negativnom smislu, baštinu prave vjere u Boga i prave Crkve . $^{29}$ 
Ovdje, dakle, nije riječ o suprotstavljanju kršćanske misli sekularnoj, nego o podvrgavanju obje sudu Isusa Krista posredovanog u biblijskoj objavi ili kristološkom prevrednovanju odnosa Krista, kršćanske zajednice i sekularne misli. Isus Krist je za Bonhoeffera »kontra-Logos« koji se »ukazuje u povijesti, ne više kao ideja, nego kao utjelovljena 'Riječ' « i zato »više ne postoji mogućnost njegove asimilacije u postojeći poredak ljudskog logosa «. ${ }^{30}$ Upravo ovakvo stanje kršćanske Crkve, s jedne strane, i razvoj sekularne misli, s

Jewish and Christian Apocalyptic Literature, T\&T Clark, London 2016., doi: https://doi. org/10.5040/9780567667304; N. T. Wright, Paul and His Recent Interpreters, SPCK, London 2016.; Barry R. Matlock, Unveiling the Apocalyptic Paul, T\&T Clark, London 1996., doi: https://doi.org/10.5040/978147 4213998; Kyle Gingerich Hiebert, The $A r-$ chitectonics of Hope: Violence, Apocalyptic, and the Transformation of Political Theology, Cascade Books, Eugene 2017.

11

Martinus C. de Boer, »Paul and Apocalyptic Eschatology«, u: J. J. Collins (ur.), The Encyclopedia of Apocalypticism, str. 345-383, str. 350 .

12

Miroslav Volf, »Soft Difference: Theological Reflection on the Relationship Between Church and Culture in 1 Peter«, Ex Auditu 10 (1994), str. 15-30, str. 17.

13

Michael A. Gillespie, The Theological Origins of Modernity, Chicago University Press, Chicago2008., str. 1-18, doi: https://doi.org/10.7208/ chicago/9780226293516.001.0001. Vidjeti, također: Hans Blumenberg, Legitimacy of the Modern Age, preveo Robert M. Wallace, The MIT Press, Cambridge 1989.; Amos Funkenstein, Theology and the Scientific Imagination from the Middle Ages to the Seventeenth Century, Princeton University Press, Princeton 1986.; Gary Dorrien, Kantian Reason and Hegelian Spirit: The Idealistic Logic of Modern Theology, Wiley Blackwell, Oxford 2015. doi: https://doi.org/10.1002/97814443555918.

14

»Najdublja neslaganja u razdoblju između četrnaestog i sedamnaestog stoljeća nisu bila ontološka, nego ontička, nisu to bila neslaganja o naravi bića, nego o tome koja od tri područja bića, ljudsko, božansko ili prirodno, ima prioritet. Jednostavno rečeno, neslaganje poslijeskolastičkih mislioca nije bilo oko samog bića, nego hijerarhije unutar bića. «Vidi: M. Gillespie, The Theological Origins of Modernity, str. 16. Ovome treba dodati Vanhoozerov uvid u teološku misao von Balthasara čija genealogija moderne, a time i kasno moderne misli, prepoznaje uzrok ovakvog razvoja u obratu koji je donio Duns Škot. On je prvi »usvojio averističko tumačenje Aristotela koji je filozofiji pristupao kao sveobu- hvatnoj znanosti o biću, prema kojoj je 'biće' univočni pojam primjenjiv i na stvoreno $\mathrm{i}$ nestvoreno. Dvostruka je posljedica ovakvog tumačenja. Ontološki, time se niječe Božja transcendencija; biće je ono što stvorenje i Bog zajedno dijele. Epistemološki, time se umu nudi magna carta za neovisnu spoznaju svega što ima biće bez pomoći otkrivenja (...).« Vidi: Kevin J. Vanhoozer, »Theology and the condition of postmodernity: A report on knowledge (of God)«, u: Kevin J. Vanhoozer (ur.), The Cambridge Companion to Postmodern Theology, Cambridge University Press, Cambridge 2003., str. 3-25, str. 21, doi: https://doi.org/10.1017/ccol052179062x.

15

Usp. Jacques Ellul, Hope in Time of Abandonment, preveo Edward C. Hopkin, Wipf \& Stock Publishers, Eugene 2012.

16

M. Gillespie, The Theological Origins of Modernity, str. 16. Ovakvo razumijevanje korijena reformacijske i moderne misli dovodi u pitanje suviše jednostranu teoriju o sekularizaciji religijskog koja je u nekim znanstvenim krugovima i dalje dominantna sociološka paradigma kojom se objašnjavaju začeci i razvoj moderne i kasnomoderne misli.

17

David Tracy, On Naming the Present: God, Hermeneutics and Church, Orbis Books, Maryknoll 1994., str. 41; David Tracy, »Theology and Many Faces of Postmodernity«, Theology Today 51 (1994) 1, str. 104-114, doi: https://doi.org/10.1177/0040573694051 00109. Vanhoozer odgovara na ovaj problem tako što predlaže remitologizaciju teologije kojom se poštuje izvornost i singularnost biblijske poruke, a istovremeno se ozbiljno uzimaju u obzir i suvremene znanstvene misli. Vidi: Kevin J. Vanhoozer, Remythologizing Theology: Divine Action, Passion, and Authorship, Cambridge University Press, Cambridge 2010., doi: https://doi.org/10.1017/ cbo9780511675959.

18

Za detaljnije razumijevanje načela Sola Scriptura vidi: John C. Peckham, Canonical Theology: The Biblical Canon, Sola Scriptura, and Theological Method, Wm. B. Eerdmans Publishing Co., Grand Rapids 2016.; John Webster, Word and Church: Essays in Christian Dogmatics, T\&T Clark Ltd., Edinburg 
druge strane, zahtijevaju sadržajno preusmjeravanje reformacijske teološke misli ako se želi odgovoriti na globalna stremljenja za mirom, pravdom i slobodom.

\section{Božansko-ljudska odnosnost}

Ako prihvatimo širi kontekst Moltmannove tvrdnje da je »jednostavno i istinito reći da teologija ima samo jedan, jedini problem: Boga «, ${ }^{31}$ pitanje o naravi Božjega konkretnog učešća u povijesnom životu pojedinaca i naroda može se uzeti kao polazišna točka za stvaralačko preusmjeravanje reformacijske baštine u dijalogu sa suvremenim misaonim strujanjima. ${ }^{32}$ Ono treba početi življenjem specifičnog eshatološkog novuma, sadržanog u Božjoj samoobjavi, na kojem se temelji obećanje o preobrazbi i novom stvaranju cjelokupnog stvorenog svijeta. Ovaj eshatološki novum ukorijenjen je u objavi (apokalipsi) Isusa Krista koja zahvaća i preobražava ljudsku prošlost i sadašnjost te u vidokrug ljudske svijesti uvodi sliku utjelovljenog i uskrslog Boga koji dolazi dovršiti preobrazbu svijeta za koji je umro. Riječi »Evo, sve novo činim.« (Otk 21,5) navješćuju Krista koji činom novog stvaranja stapa i onostrani i ovostrani vid božansko-ljudskog odnosa i djelima radikalne ljubavi postupno preoblikuje svijet otuđen od Njega. ${ }^{33}$

Prije nego što detaljnije razložim narav i konkretne učinke ove radikalne ljubavi, želim se osvrnuti na Ellulovo tumačenje otuđenosti zapadnog čovjeka od Boga. On je opisuje pojmom odbačenosti koja se očituje tako što On na sve dvojbe i nadanja suvremenog čovjeka odgovara šutnjom i skrivenošću. ${ }^{34}$ Ova Božja otuđenost od društva i njegovih institucija događa se u ozračju izopačenog zapadnog sustava vrednota, determinizma struktura tehnološkog društva koje čovjeka drži u »zatvorenom svijetu« bez nade u budućnost $\mathrm{i}$ ispunjenog bujanjem iracionalnog. Suvremeni čovjek je, tvrdi on, odbacivši Riječ prihvatio idole novog doba i okončao u očaju i samoprijeziru. Umjesto razvijanja kritičkog intelekta, slijed njegova razvoja, posve suprotno naraciji moderne, ne ide od mita k razumskoj spoznaji, nego okončava u novim mitologijama $\mathrm{u}$ obliku erotičnosti, zabava, pohlepe i besmislene potrošnje. ${ }^{35}$

Odgovor je u kršćanskoj nadi koja predstavlja pobjedu nad svime što se suprotstavlja životu u zajednici s Bogom. Kada dosegnemo kraj svojih iluzornih nada, tvrdi Ellul, tada se rađa autentična nada koja se očituje u realizmu, u ustrajnom čekanju, u molitvi kojom se borimo s Bogom i tražimo da progovori. Da bi život kršćana bio znak koji društvo usmjerava Bogu, oni su pozvani živjeti nadu u Krista tako što će kao pojedinci ili zajednica vjernika odbiti pritisak i sociološke i duhovne asimilacije. Nada je teološka vrlina koju treba iskusiti, a ne samo artikulirati na razini objektiviziranog pojma. Punina nade živi se u odnosu s Bogom i stoji nasuprot postojećeg mediokritetskoga kršćanskog svjedočenja i prisutnosti u svijetu kojim se nastavlja njihovo beznađe.

Ellul posebno ističe misao o nadi koja donosi slobodu tako što relativizira svijet i povijest jer savršeni mir, sloboda i pravda dolaze samo kao posljedica Božjeg suda na kraju povijesti. Ovaj Božji čin milosti oslobađa nas od idolopokloničkih, utopijskih shema i apsolutiziranja nacije, rase ili ideologije. »Sloboda je«, za Ellula, »etički izričaj osobe koja se nada. Nada je odnos s Bogom osobe koju je Bog oslobodio« ${ }^{36}$ Ovakva nada potiče etičko djelovanje jer »Božji apsolut doista relativizira sve, ali Božja Riječ nam govori da ovo relativno koje je On dovoljno ozbiljno prigrlio da je dao svog Sina, shvatimo apsolutno ozbiljno . $^{37}$ 
Značaj je ove nade za sadašnji život u tome što nas ona ne osposobljava da očistimo, preobrazimo ili ovladamo svijetom, nego da svako djelo bude istinski »znak« ili prikaz Božje obećane budućnosti. Nada je, za Ellula, egzistencijalni stav spram Boga i svijeta radije nego karakterna vrlina u aristotelijanskom i tomističkom smislu. Ovdje nije riječ o navici ili kultiviranju sklonosti, nego o odlukama koje se uvijek iznova donose u sadašnjosti. Božja posvećujuća milost zajedno sa svjesnim, opetovanim djelima ljubavi preobražavaju karakter osobe koju niz presudnih odluka vodi autentičnoj slobodi.

2001., str. 9-46, doi: https://doi.org/10.50 40/9780567668660.

19

U američkoj teologiji dvadesetog stoljeća Tracy i Ricœur pripadaju takozvanoj čikaškoj školi (»The Chicago School«), dok Frei pripada postliberalnoj teološkoj struji (»The Yale School $)$.

20

Hans Frei, The Eclipse of Biblical Narrative. A Study in Eighteenth and Nineteenth Century Hermeneutics, Yale University Press, New Haven, London 1974. Za drugačije razumijevanje ovog pitanja, koje i Frei i Ricœur nazivaju "pomrčinom biblijske naracije $\ll$, vidi: Paul Ricœur, Time and Narrative, sv. 1, preveli Kathleen McLaughlin, David Pellauer, University of Chicago Press, Chicago 1990., str. 90-120

21

Charles Taylor, Secular Age, Harvard University Press, Cambridge 2007., str. 1-4. U tom kontekstu zanimljiva je i Bergerova izjava: »Mislim da je ono što smo ja i većina sociologa religije pisali u 60-ima o sekularizaciji bila pogreška. Naš temeljni argument je bio da sekularizacija i moderna idu ruku pod ruku.« Vidi: Peter Berger, »Epistemological Modesty: An interview with Peter Berger«, Christian Century 114 (1997), str. 972-978, str. 972-975, 978.

22

C. Taylor, Secular Age, str. 648.

23

Ibid., str. 26.

24

Za definiciju pojma »socijalna imaginacija (social imaginary), ključnog za razumijevanje Taylorove teorije sekularizacije, vidi: C. Taylor, Secular Age, str. 146, 159-211.

25

C. Taylor, Secular Age, str. 505-535. Terry Eagleton ih, primjerice, prepoznaje u brojnim zamjenskim utjelovljenjima prognanog Boga Tako se On javlja manje ili više skriven kao Um, Priroda, Geist, kultura, umjetnost, uzvišeno, narod, država, znanost, čovječanstvo, biće, društvo, drugi, želja, životna sila. Usp. Terry Eagleton, Kultura i smrt Boga, prevela Petra Štrok, Naklada Ljevak, Zagreb 2015. str. 56.

\section{6}

Vidi Bonhoefferov odgovor na pitanje o čovjekovoj spoznaji i vršenju Božje volje: Dietrich Bonhoeffer, Etika, preveo Alen Kristić, Ex Libris, Synopsis, Rijeka, Sarajevo 2009. str. 90-91.

27

M. Volf, Isključenje i zagrljaj, str. 39. Ovako konstituiran identitet posve je oprečan Bonhoefferovu poimanju identiteta ukorijenjenog u Božjoj ljubavi i vršenju Njegove volje kao odgovora na »propast svijeta«. Vidi: D. Bonhoeffer, Etika, str. 73-102.

28

D. Bonhoeffer, Etika, str. 141. Iako ih Taylor gotovo i ne spominje, korisno bi bilo imati na umu teološke i filozofske doprinose R. Bultmanna, P. Tillicha, A. McIntayra i J. Stouta dijalogu kršćanske i sekularne misli.

29

Ibid., str. 141, 142.

30

Dietrich Bonhoeffer, Christology, Collins, London 1978., str. 28. Za primjer kristologije koja je bliže izvornom biblijskom prikazu Krista vidi također: J. Webster, Word and Church, str. 113-190, doi: https://doi.org/10. 5040/9780567668660

31

Jürgen Moltmann, Theology and the Future of the Modern World, ATS, Pittsburgh 1995., str. 1. Volf iznosi identičnu misao kada tvrdi da je Bog »budućnost teologije«. Vidi: Miroslav Volf, »Introduction«, u: Miroslav Volf (ur.), The Future of Theology: Essays in Honour of Jürgen Moltmann, Wb. M. Eerdmans Publishing Co., Grand Rapids 1996., str. ix-xviii, str. xvii

32

Vidi: C. Taylor, Secular Age, str. 539-776; K. J. Vanhoozer, Remythologizing Theology; Kevin J. Vanhoozer, »Theology and the Condition of Postmodernity«, u: K. J. Vanhoozer, The Cambridge Companion to Postmodern Theology, str. 3-25, str. 19, doi: https://doi. org/10.1017/ccol052179062x.

33

Zanimljivo bi bilo usporediti Taylorovo ( $\mathrm{Se}$ cular Age) i Bonhoefferovo (Etika) poimanje uloge ljubavi u obnovi kršćanske zajednice i njezina utjecaja na širu društvenu zajednicu. 
Nadalje, pojmiti Boga izvan logosa moderne znači dosljedniju teološku primjenu Moltmannove distinkcije između pojma adventus i futurum. ${ }^{38}$ Adventus opisuje budućnost koja ne proizlazi iz sadašnjosti, nego donosi radost budućeg otkupljenja, iščekivanje nečega novog i preobražavajućeg što do sada nije bilo prisutno u sadašnjosti. On opisuje Boga koji dolazi, Boga koji je naviješten u proročkim i apostolskim navještajima nade. Cilj ovoga Kristova dolaska u svijet njegova je potpuna preobrazba u skladu s otkupiteljskim nakanama za svekoliko stvorenje. Riječ je, dakle, o Bogu koji je jedan i jedinstven, poseban i neusporediv, Bogu koga ljudska tumačenja i poimanja povijesti, bića ili budućnosti ne mogu i ne smiju ograničavati. Smrt i uskrsnuće Isusa Krista te djelatna prisutnost Duha Svetoga jamče budućnost koja već prožima ljudsku sadašnjost, a potpuno se razlikuje od futuruma koji predstavlja ovostrano produženje bića, nečega što je već sadržano u sadašnjosti. ${ }^{39}$ Zato Moltmann može reći:

»Prisutnost opravdanja i pomirenja početak je ove preobražavajuće i promijenjene budućnosti (Zukunft) božanske pravednosti u nepravednoj i nepomirenoj egzistenciji. «0

Ovdje je ključno zapaziti da Moltmann zagovara poimanje Boga koji svojim božanskim sadržajima, posve jedinstvenim eshatološkim novumom, prožima sadašnjost i otkriva postojanje i djelovanje nove stvarnosti koja već sada najavljuje ono konačno i potpuno otkrivenje Boga sažeto u Pavlovim riječima:

»Što oko ne vidje, i uho ne ču, i u srce čovječje ne uđe, to pripravi Bog onima koji ga ljube.« (1 Kor 2,9)

Jedinstvenost ovakvog eshatološkog i kristološkog novuma vidljiva je i u Bonhoefferovu tumačenju odnosa čovjeka i Krista:

»Pravo, istina, ljudskost i sloboda traže utočište kod raspetog i patećeg Krista u njegovoj zajednici, kod onoga koji u svijetu ne nalazi prenoćišta, kod iz svijeta izbačenog Krista (...). Pod njegovu zaštitu bježe i tek na taj način on objavljuje cjelokupnu širinu svoje moći. « ${ }^{41}$

Ovdje je riječ o apokaliptičkoj teologiji koju s različitim naglascima zagovaraju Beker, Gaventa, de Boer, a Ziegler ${ }^{42}$ ovako opisuje njezino poimanje božanskog djelovanja u povijesti:

»... u Pavlovu evanđelju 'otkrivenje' (apokalypsis) označava Božje otkupiteljsko osvajanje grešnog poretka tako da je sama zbilja presudno preoblikovana u tom događaju. Božji advent u Kristu potpuno raskida i izmješta prethodne obrasce mišljenja i djelovanja te uvodi nove koji bolje pristaju sa stvarnošću svijeta aktivno pomirenog s Bogom. Ovo se posebno odnosi na međusobnu povezanost teologije i etike. Evanđelje neizbježnog suda i prekomjernog oprosta čini svijet novim, i stoga i nove, apokaliptičke antinomije mijenjaju one antinomije koje su do sada strukturirale teološku i etičku refleksiju i prosudbu. Apokaliptika je, prema ovom gledištu, više od puke retorike: Ona je oblik diskursa sposoban dati glas radikalnim ontološkim i epistemološkim posljedicama ovakvog evanđelja, posljedicama koje su presudno važne za bavljenje kršćanskom etikom. $\aleph^{43}$

Ključno je obilježje ovakve apokaliptike poistovjećivanje otkrivenja s pomirenjem:

»Ona označava razumijevanje Krista kao 'učinkovito i definitivno očitovanje Božjeg spasonosnog djelovanja' čime je stari 'svijet ili doba uništeno i okončano'. Doista, apokaliptika je kratica za osebujno priznanje identiteta i važnosti Isusa Krista. Pavao svjedoči da je ono što se događa u Kristu učinkovit prodor Božje sile u svijetu. Otkrivenje nije 'puko očitovanje prethodno skrivenih tajni ili jednostavno informacije o budućim događajima'. Samo otkrivenje je i događaj koji uvodi, istovremeno dok otkriva, novo stanje stvari; otkrivenje, ne samo da 'obznanjuje', nego i 'krči put' uključujući Božje odlučno 'djelovanje i pokretanje, invaziju donjeg svijeta s Neba'. Događaj u kojem se Bog obznanjuje kao Spasitelj, dolazak Krista, je događaj koji sam po sebi spašava. Otkrivenje je stoga i pomirenje. $\aleph^{44}$

Slično poimanje uloge apokaliptike u suvremenoj teologiji vidi i Walter Lowe kada tvrdi da: 
»Suspenzija svega ljudskog u bezuvjetnoj apokalipsi, suspenzija koja je bezuvjetna zato što je apokaliptična, možda je mogućnost koju je teologija krize načas spazila.« ${ }^{45}$

Ipak, ovakvo poimanje apokaliptike ne smije, prema Bonhoefferu, ostati samo na razini akademske rasprave, nego treba presudno obilježiti život kršćanske zajednice koja treba »biti osebujna i biti zajednica koja sluša apokaliptiku«. ${ }^{46}$ Primjeri koji dodatno osnažuju razloge za ovakvim osebujnim razumijevanjem apokaliptičke eshatologije mogu se, prema Adamsu, prepoznati u negativnim učincima teološkog usvajanja filozofskog tumačenja vremena i povijesti u suvremenim razlaganjima kršćanske eshatologije u djelima Pannenberga, Rahnera i Moltmanna. ${ }^{47}$

\section{Novi čovjek}

Reformacijska teološka baština treba svjedočiti ovaj prodor božanske stvarnosti u osobi Isusa Krista i djelovanje Duha Svetoga kojim On polaže temelj za ostvarenje mira, slobode i pravde tako što upućuje "na svaku istinu « i navješćuje »ono što dolazi« (Iv. 16,13). Ovakvim stapanjem sadašnjeg i eshatološkog vida božanske djelatne prisutnosti rastaču se stari obrasci življenja te ustanovljuju novi život i novi svijet unutar novoga kolopleta odnosa Boga, čovjeka i svijeta. Ipak, prikladno je pitati kako ovi ideali pomirenog svijeta, ideali cjelovite slobode, pravde i mira mogu, poput metaforičkoga kvasca,

34

J. Ellul, Hope, str. 74-97. Usp. C. Taylor, Secular Age, str. 553.

35

J. Ellul, Hope, str. 65, 75-77.

36

Jacques Ellul, The Ethics of Freedom, preveo Geoffrey W. Bromiley, Wm. B. Eerdmans Publishing Company, Grand Rapids 1976. str. 239.

37

J. Ellul, Hope, str. 242. Usp. »Slobodu je stvorio Bog za čovjeka i u čovjeku. Ako je nada čovjekov odgovor na Božju ljubav i milost, onda je sloboda Božji odgovor na čovjekovo nadanje, dajući mu mogućnost življenja nade konkretno i djelotvorno u svakodnevnom životu (...). Stoga postoji stroga uzajamnost između nade i slobode. Bog ljubi, čovjek se nada i Bog oslobađa.« Vidi: J. Ellul, The Ethics of Freedom, str. 13.

38

Vidjeti članak N. Adamsa u kojem on, između ostalog, problematizira Moltmannovo nekritičko usvajanje Blochova poimanja nade: »Kada Moltmann koristi Blochov govor o budućnosti on istovremeno koristi Blochovu estetsku zamjenu za teologiju i njegovu zamjenu Krista utopijskom funkcijom.« Vidi: Nicholas Adams, »Eschatology Sacred and Profane: The Effects of Philosophy on Theology in Pannenberg, Moltmann, and Rahner«, International Journal of Systematic Theology 2 (2000) 3, str. 283-306, str. 303, doi: https:// doi.org/10.1111/1463-1652.00041.
39

Jürgen Moltmann, The Future of Creation, SCM Press Ltd., London 1979., str. 29-30.

40

Ibid., str. 30 .

41

D. Bonhoeffer, Etika, str. 106.

42

Philip Ziegler, »Dietrich Bonhoeffer - An Ethics of God's Apocalypse«, Modern Theology 23 (2007) 4, str. 579-594, doi: https:// doi.org/10.1111/j.1468-0025.2007.004 43

P. Ziegler, »Dietrich Bonhoeffer«, str. 580. Vidi također: J. Christiaan Beker, Paul's Apocalyptic Gospel: The Coming Triumph of God, Fortress Press, Philadelphia 1982., str. 30-53.

44

P. Ziegler, »Dietrich Bonhoeffer«, str. 581.

45

Walter Lowe, »Prospects for a Postmodern Christian Theology: Apocalyptic Without Reserve «, Modern Theology 15 (1999) 1, str. 1724, str. 23, doi: https://doi.org/10.1111/14680025.00083 .

46

D. Bonhoeffer, No Rusty Swords, str. 324.

47

N. Adams, »Eschatology Sacred and Profane«, str. 3, doi: https://doi. org/10.1111/14631652.00041 . 
prožeti suvremena društva kao djelatan znak nazočnosti nebeskoga kraljevstva.

Primjeren odgovor na ovo pitanje ne može se dati bez daljnjeg razmatranja suodnosa Boga, čovjeka i svijeta u apokaliptičkoj teologiji. Kristov čin pomirenja Boga i svega stvorenog na križu temelj je za oblikovanje »novog stvora« (Gal 6,14; 2 Kor 5,17), čime se radikalno poništava stanje ljudskog sužanjstva u grijehu i nudi dar obnovljenog života u Isusu Kristu kao trajna odrednica ljudske egzistencije. Volf upravo to smatra središnjom temom Novog zavjeta $\mathrm{i}$ ističe istinu o trojednom Bogu koji je činom opravdanja i uskrsnuća Isusa Krista darovao sebe svijetu (Rim 5,6 $)^{48}$ i tako ga istrgnuo iz smrtonosnog zagrljaja nasilja, neprijateljstva i patnje te otvorio nova obzorja obnovljenog života. Kada se svijet susreo s Bogom u činu Kristove smrti i uskrsnuća, kada je Božji raspeti Logos razotkrio manjkavosti ljudskog logosa, za čovjeka više nema »prostora, vremena, pojma ili dijela stvaranja izvan ili iznad kojeg presudno, odlučno i konačno Božje djelovanje u Isusu Kristu nije odredilo«. ${ }^{49}$ Bog je u Kristu, Emanuelu, zagrlio otuđeni svijet i tim činom pozvao svoje sljedbenike da čine isto.

Ali što točno znači prigrliti otuđeni svijet u suvremenim europskim društvima? Mogu li kršćani, nakon neuspjeha moderne vjere u neminovan boljitak svijeta, doprinijeti iscjeljenju, preobraženju Crkve te ovo novo stanje koje je Bog ustanovio ugraditi u društva s kojima su neraskidivo povezani? Što točno znači dati sebe svijetu ili prigrliti svijet? Što treba, po uzoru na Isusa Krista, biti sadržaj vjerničkog davanja samog sebe svijetu?

Kristovim činom pomirenja ustanovljen je novi poredak u kojem se u utjelovljenom Isusu Kristu stapaju vremeniti i nadvremeniti poredak u novu zbilju pomirenu s Bogom kroz Njegovu smrt, uskrsnuće i sud. Krist svojom prisutnošću urušava misaoni svijet grešnog svijeta i lišava ga njegova diskurzivnog izričaja i umjesto toga uvodi govor Božje riječi (Heb 4,12) i božanske kategorije pokajanja, oprosta, pomirenja i novog stvaranja kao dominantne sadržaje novog života s Bogom.

Prvi korak je »Opravdanje« koje je, prema Bonhoefferu:

»... čisto samo-otkrivenje, čisti Božji put čovjeku. Nikakva religija, nikakva etika, nikakva metafizička spoznaja ne može pomoći čovjeku da pristupi Bogu. Samo priznanje da samo Božja Riječ pomaže i da svi drugi pokušaji jesu i ostaju grešni, samo ovakvo priznanje Bog prima. «50

On u ovom teološkom uvidu o krivnji i oprostu ističe ključnu ulogu božanski obnovljene Crkve u posrednoj obnovi zapadnog svijeta. Ona treba pozivati pojedince u zajedništvo priznanja krivnje i oprosta i tako uvesti ljude u zajednicu s uskrslim i živim Kristom. Ako to ne bi bilo tako, »Crkva više ne bi bila Crkvom«. Ona je prostor u kojem se ozbiljuje spoznaja krivnje. ${ }^{51}$ On zatim naglašava jasnu distinkciju između oprosta koji podrazumijeva potpuni raskid s krivnjom i novi početak, a moguć je samo za Crkvu i pojedinca u zajednici s Kristom dok u povijesnom životu naroda krivnja i dalje ostaje. Izvan Crkve i osobnog odnosa s Bogom u povijesnom i političkom životu naroda moguć je postupni proces ozdravljenja koji je ipak samo puka sjena oproštenja koje Isus Krist daruje vjerniku. ${ }^{52}$ Potpuna obnova cjelokupnog svijeta bit će ostvarena tek u Kristovoj novoj stvarnosti na kraju vremena u trenutku kada Kristov dolazak i sud okončaju zlo i činom se novog stvaranja uspostavi punina Božjega kraljevstva.

Ovu distinkciju između različitih ishoda u procesu priznanja krivnje i primanja oprosta može se primijeniti i na pitanja mira i slobode. Naime, pomirenje čovjeka s Bogom u kojem presudnu ulogu igra svijest i priznanje krivnje te 
primanje oprosta, temeljni je preduvjet za postepeno ostvarenje mira i slobode i u osobnom i društvenom životu pojedinaca i naroda. Svjedočenje ove kvalitativne razlike između božanskog dara mira i svjetovnog mira razvidne iz Iv 14,27 zadaća je koja stoji pred zagovarateljima vrijednosti reformacijske teološke baštine. Vjerodostojno i ustrajno svjedočenje ove teološke razlike dio je doprinosa koji oni mogu ugraditi u društveno tkivo europskih naroda i konkretno prikazati učinke vjere u Božju prisutnost u ovom vremenitom poretku. U korijenu je ovakvog poimanja božansko-ljudskog supostojanja biblijski nauk o grijehu koji je nedjeljivi dio reformacijske teološke baštine. ${ }^{53}$ Duga povijest reinterpretacije zla, koju ovdje nije moguće niti sažeto prikazati, odgovorna je za suvremenu zatvorenost za Božju prisutnost i svjedočenje Duha Svetog o naravi grijeha (Iv 16,8). Pojednostavljeno rečeno, suvremena zapadna društva obilježena su dvjema krajnostima u poimanju zla. Prva je sadržana u poznatom R. Niebuhrovu uvidu o »mirnoj savjesti« novovjekovnog čovjeka. »Suvremeni čovjek u suštini ima mirnu savjest «, tvrdi on, »i ništa ne daje takav sklad raznolikim i neusuglašenim tonovima suvremene kulture kao jednodušno protivljenje suvremenog čovjeka kršćanskom poimanju čovjekove grešnosti«. Iako je, nastavlja on:

»Suvremena povijest ispunjena očitovanjima čovjekovih histerija i srdžbi, dokazima njegove demonske sposobnosti i sklonosti razaranju prirodnog sklada i prkošenja razboritim kanonima racionalne suzdržljivosti (...), ipak, čini se da nikakva kulminacija protudokaza ne može poremetiti dobro mišljenje suvremenog čovjeka o samom sebi. ${ }^{54}$

S druge strane, James K. A. Smith ukazuje na drugu krajnost u poimanju zla u postprosvjetiteljskoj misli ili, točnije, u okrilju postmetafizičke misli. Ona pretpostavlja da su "praiskonsko nasilje i sukobljeni odnosi upisani u samu narav stvari, u strukturu stvaranja«, što znači da se »nasilju ne može oduprijeti, ne može ga se iskorijeniti, nego samo umanjiti«. ${ }^{55}$ Gotovo identičnu misao ističe i David Bentley Hart i ukazuje na mogući izvor ove krajnosti:

»Međutim, izvjesni pravac u suvremenoj filozofiji tvrdi kako je nasilje jednostavno neizbježno. Gdje god je Nietzscheova naracija o volji za moć, utkana u temeljna načela filozofske refleksije, iznjedrila partikularnu praksu kritičke sumnje, ukorijenila se duboka predrasuda, što znači da je učinak svođenje svakog diskursa na diskurs moći i svake retoričke transakcije na pojavu izvornog nasilja. Iz ove točke motrišta retorika je mira po definiciji dvoličnost (...). « ${ }^{56}$

48

Miroslav Volf, Isključenje i zagrljaj: teološko promišljanje identiteta, drugosti i pomirenja, prevela Bruna Filli-Terišak, STEPress, Zagreb 1998., str. 26.

49

Douglas Harink, Paul Among the Postliberals: Pauline Theology Beyond Christendom and Modernity, Wipf \& Stock Publishers, Eugene 2013., str. 69

50

Dietrich Bonhoeffer, »Concerning the Christian Idea of God«, Journal of Religion 12 (1932) 2, str. 177-185, str. 185. doi: https:// doi.org/10.1086/481157.

51

D. Bonhoeffer, Etika, str. 148.

52

Ibid., str. 150
53

Vidjeti Sigve Tonstad, God of Sense and Traditions of Non-Sense, Wipf and Stock Publishers, Eugene 2016. Tonstadovo djelo predstavlja kreativan pokušaj ponovne afirmacije tradicionalnog reformacijskog poimanja zla.

54

Reinhold Niebuhr, The Nature and Destiny of Man, sv. 1, Westminster John Knox Press, Louisville 1996., str. 23, 94.

55

James K. A. Smith, Introducing Radical Orthodoxy: Mapping a Post-Secular Theology, Grand Rapids, Baker Academic 2004., str. 195-197.

56

David Bentley Hart, The Beauty of the Infinite: The Aesthetics of the Christian Truth, W. B. Eerdmans, Grand Rapids 2003., str. 2. 
Zato Lutherovo razumijevanje zla kao konkretnog povijesnog fenomena, čije se dokinuće očekuje na kraju povijesti, predstavlja važnu ravnotežu između ove dvije krajnosti. Koliko ozbiljno Luther shvaća stvarnost grijeha, vidljivo je i iz sadržaja njegove prve teze:

»Kada naš Gospodin i Učitelj Isus Krist reče: 'Pokajte se' itd. (Mt 4,17; Mk 1,15) zaželio je da čitav život vjernika bude pokajanje. $\aleph^{57}$

Ovo je biblijski zahtjev kojim se čovjeka poziva da zajedno s Kristom, pobjednikom nad grijehom i Pomiriteljem, činom kajanja postane baštinik ove nove stvarnosti koju On postepeno uvodi u ovaj vremeniti poredak. ${ }^{58}$

Upravo zato reformacijska teologija ne povezuje pokajanje samo s liturgijom nego i sa sveukupnošću praktičnog života pojedinca i zajednice vjernih. ${ }^{59}$ Ono utire put preobrazbi čovjeka u odnosu s Bogom i predstavlja čin pomirenja kojim se mir i sloboda uprizoruju u životima pojedinaca i zajednica vjernih nudeći ga kao dar na kojem se temelji nada u obnovljeni život i svijet. Suprotno Foucaltovoj tvrdnji o kršćanstvu kao »konfesionalnoj religiji« u kojoj je vjernik prisiljen svjedočiti protiv samog sebe, ${ }^{60}$ reformacijska teološka baština vidi ovaj čin kao življenje dara milosti kojim se otvara put za konačno i potpuno oslobođenje čovjeka od okova smrti i samouništenja. Svjedočenje mira i pravde, prema reformacijskom razumijevanju punine kršćanskog života, počinje primanjem temeljnog dara slobode od grijeha u činu pokajanja i oprosta, čime se u vremenitom poretku ozbiljuje Božja preobražena stvarnost i navješćuje konačni kraj zla.

Preobrazbom koja počinje činom kajanja čovjek već sada ulazi u okrilje Božje nove stvarnosti i prima dar slobode koja utemeljuje sve ostale inačice osobnih i društvenih sloboda. Ovaj primarni oblik slobode nova je, darovana zbilja koja omogućuje čovjeku da uvijek iznova spoznaje istinu o Bogu, o sebi i o svijetu izvan onoga što Taylor naziva »imanentnim humanizmom«. Ovakav obnovljeni odnos čovjeka i Boga otvara put da se sloboda, pravda i mir upisuju u kulturna obzorja suvremenih društava jer samo osoba pomirena s Bogom kroz iskustvo slobode može razumjeti i činiti istinu i pravdu te graditi mir. Kada ljudski život biva konstituiran djelovanjem Božje prisutnosti koja počiva izvan djelokruga ljudskog iskustva, time se posredno priznaje da samo Bog može nadvladati zlo i ustanoviti konačnu vladavinu mira, pravde i slobode. ${ }^{61} \mathrm{Na}$ tom je tragu »Pavlovski humanizam«, otvoren za božansku djelatnu prisutnost sadržanu u pozivu na oblikovanje identiteta pojedinca i zajednica $» u$ Kristu« $(2$ Kor 5,17$),{ }^{62}$ na proročko življenje, da bi otpočeo proces otkupljenja povijesti koju se uvijek iznova otkriva u osobnom i socijalnom vidu čina kajanja i oprosta. Tako se Kristovo sebedarje pretače u partikularni oblik sebedarja pojedinaca i kršćanskih zajednica svijetu u kojem su one našli svoj dom $\mathrm{i}$ identitet.

\section{Završna razmatranja}

Ipak, ovo božansko i ljudsko sebedarje može polučiti vidljive rezultate ako počiva na humanizmu otvorenom ne samo za božansku transcendenciju nego i za otvorenost spram kulturnih strujanja u kojima kršćani prebivaju. Posebno treba istaknuti dva oblika ove otvorenosti koja mogu biti poticaj plodonosnom dijaloškom pluralizmu nužnom za dijalog teologije i znanosti. Prvo, ako je nešto razvidno iz teoloških, socioloških, povijesnih i političkih raščlambi izvorne reformacije, to je uvid da se značajniji utjecaj reformacijske teološke baštine na suvremena europska društva može ostvariti samo u sinergiji sa 
širim kulturnim strujanjima. Stoga je iznimno važno ustrajati na traganju za inkluzivnim metodološkim i teorijskim okvirima nužnim za otvoren i ravnopravan dijalog reformacijske teološke misli i europskih kulturnih strujanja. Cilj je omogućiti ravnopravnu razmjenu ideja i međusobno obogaćivanje znanosti i religije bez jednostranog apsolutiziranja vlastitih znanstvenih ili teorijskih uvida i metodoloških pristupa te znanstvenog redukcionizma kojim se iz dijaloga isključuju sva ona stajališta koja nemaju visok stupanj podudarnosti sa znanstvenim postulatima jedne strane. Brad S. Gregory ukazuje na primjer ovakvog apsolutiziranja vlastitih znanstvenih pretpostavki u tumačenju povijesti kada se postulira istiskivanje prethodnih, navodno primitivnih svjetonazorskih paradigmi u ime novih, progresivnih poimanja znanosti, religije ili povijesti. On, primjerice, s pravom problematizira gledište kojim se povijest, ili bilo koja druga znanstvena disciplina, smatra ili nebitnom za razumijevanje suvremenih društvenih procesa ili se tumačenje suvremene zapadne kulture ograničava na znanstvenu revoluciju, prosvjetiteljstvo, industrijalizaciju ili pojavu suvremenog kapitalizma. ${ }^{63}$

Drugo, Taylorov postulat o promijenjenim »uvjetima vjerovanja « u obliku »isključivog humanizma« zahtijeva i kratak osvrt na epistemološki vid ove dijaloške otvorenosti. Dok su u nedavnoj prošlosti pitanja o znanju o Bogu bila više ili manje ostavljana postrani, noviji pravci u općoj i religijskoj epistemologiji, koje slijedi i teološka epistemologija, nude prostor za ravnopravniji dijalog između teologije i znanosti, a time i šire kulture. ${ }^{64}$ Ako se, prema Grecu, ustraje na eksternalističkom i socijalnom zaokretu u epistemologiji kojim se odbacuje isključivost klasičnog, internalističkog fundacionalizma kao i na jasnoj distinkciji između znanja i razumijevanja te se u objašnjavanju toga što je znanje istovremeno odbaci pironovski skepticizam, otvara se pros-

57

Martin Luther, Temeljni reformatorski spisi, sv. 1, Demetra, Zagreb 2006., str. 13

58

Prema Bonhoefferu, presudna uloga pokajanja može se razumjeti samo ako se priznaje razoran učinak grijeha: „Cak i najskrovitiji grijeh pojedinca predstavlja onečišćenje i razaranje Kristova tijela«, i predstavlja »otrovni izvor za zajednicu«. Vidi: D. Bonhoeffer, Etika, str. 149.

59

Za opširnije razumijevanje pokajanja vidi: Mark J. Boda, 'Return to Me'. A biblical theology of repentance, InterVarsity Press, Downers Grove 2015.; Mark J. Bode, Gordon T. Smith (ur.), Repentance in Christian Theology, Liturgical Press, Collegeville 2006.

60

Michel Foucault, Ethics: Subjectivity and Truth, u: Essential Works of Foucault, 1954 1984, sv. 1, The New Press, New York 1997. str. 178 .

61

M. Volf, Isključenje i zagrljaj, str. 30. Ovdje je dobro napomenuti da je otkupljenje povijesti u činu osobnog i zajedničkog pomirenja Boga i čovjeka dio svemirske borbe dobra $i$ zla koju apokaliptička teologija zagovara.
62

Za opširnije razumijevanje ovog pojma iz motrišta evanđeoske teologije vidi, primjerice: Michael J. Thate, Kevin J. Vanhoozer, Constantine R. Campbell (ur.), "In Christ« in Paul: Explorations in Paul's Theology of Union and Exploration, Wm. B. Eerdmans Publishing Co., Grand Rapids 2018., doi: https://doi.org/10.1163/15697312-01002003.

63

Greg S. Boyd, The Unintended Reformation: How Religious Revolution Secularized Society, The Belknap Press, Cambridge 2012. str. 14-15, doi: https://doi.org/10.4159/harvard.9780674062 580 .

64

John Greco, »Knowledge of God«, u: William J. Abraham, Frederick D. Aquino (ur.), The Oxford Handbook of Epistemology of Theology, Oxford University Press, Oxford 2017., str. 9-29, doi: https://doi.org/10.1093/ oxfordhb/9780199662 241.001 .0001 . Za kratku raspravu o znanju o osobama vidi: Eleonore Stump, Wandering in Darkness: Narrative and the Problem of Suffering, Claredon Press, Oxford 2012., str. 23-81, doi: https://doi. org/10.1093/acprof:oso/97801992 $\overline{77421.001}$ .0001 
tor za dijalog s teološkom epistemologijom. Ona, naime, ozbiljno uzima u obzir znanje o osobama, individualna svjedočanstva, unutarnje osvjedočenje Duha Svetog, iskustveno utemeljenje teoloških vjerovanja te pitanja autoriteta u epistemologiji kao i odnos znanstvenog nasuprot običnog znanja. ${ }^{65}$ Tek prihvaćanjem ovakve epistemološke raznovrsnosti može se otvoriti put za dublje razumijevanje onoga što Bonhoeffer misli kada govori o ljubavi sadržanoj »u pomirenju čovjeka s Bogom u Isusu Kristu«, koja zvuči kao suvremeni manifest Reformacije. U ovakvoj ljubavi, tvrdi:

»Okončana je razdvojenost čovjeka od Boga, od drugog čovjeka, od svijeta i od samog sebe. Izvor mu je iznova darovan. ${ }^{66}$

\title{
Darko Pirija
}

\section{Freedom, Justice and Peace}

\section{The Future of Reformation Legacy in a Dialogue with the Contemporary Apocalyptic Theology}

\begin{abstract}
The further affirmation of Reformation theological legacy in contemporary European cultures requires its creative reinterpretation in order to make meaningful the original value of its fundamental theological content and at the same time respond to new questions and dilemmas that emanate from a stratified cultural habitus of the late modernity. Substantial redirecting of the Reformation theology should follow the logos of God's reality rather than the logos of modernity within theoretical, methodological and epistemological boundaries that will warrant a more even-handed and fruitful dialogue between theology and culture. To bring to fruition the ideals of peace, freedom and justice on the basis of faith in Christ's transforming love, it needs to be situated in the contemporary apocalyptic theology that takes seriously the traditional reformation doctrine of sin and repentance and brings together the present and future aspect of Christ's apocalypse of freedom, peace and justice. By living a new life in Christ, Christian communities can testify to the fullness of life based on the faith in the transforming effects of God's presence in history and on the hope in the final dissolution of evil in God's promised future.
\end{abstract}

\section{Key words}

freedom, peace, justice, Miroslav Volf, Charles Taylor, Jacques Ellul, Jürgen Moltmann, reformation, apocalyptic eschatology, repentance 